\title{
Recognition and treatment of law enforcement violence against detainees and prisoners: A Survey among Israeli physicians and medical students
}

\author{
Zvi Benninga,* Bettina Steiner-Birmanns,** Revital Arbel, *** Firas Abu Akar,** \\ Mushira Aboo Dia,***
}

\section{Key points of interest}

- Prisoners and detainees suffer an increased risk of violence and maltreatment but are often overlooked.

- A significant number of physicians and medical students would not report suspected instances of violence and maltreatment and even appear to support the use of torture in certain circumstances.

- Clear practice guidelines must be developed and implemented regarding the role of medical practitioners in treating such cases, with a special emphasis on documentation and reporting.

- The Israeli Ministry of Health needs to provide a clear policy of redress for any reports on violence towards detainees and prisoners.

\begin{abstract}
Introduction: Physicians regularly encounter victims of violence. Although some at-risk groups are increasingly recognized as such, the risks faced by prisoners and detainees are often overlooked. The scope of violence against them is unknown and their treatment is often hampered by unique social and institutional impediments. This article reviews the need for improved recognition and protection of such patients and the associated obstacles, while presenting information on the experience, knowledge and attitudes of physicians in Israel regarding the maltreatment of prisoners and detainees. Methods: We sent a questionnaire to physicians and medical students in Israel to enquire about their knowledge concerning examination and treatment of persons under police custody who appear to be victims of violence as well as their attitude concerning torture. Results: We received answers from

\footnotetext{
$\star \star \star \star$ ) Department of Gynecology, Hadassah University Hospital, Jerusalem, Israel.
}

Correspondance to: bbirmanns@gmail.com
\end{abstract}

*) Hadassah University Hospital, Jerusalem, Israel

$\star \star$ ) Department of Neurology, Shaare Zedek Medical Center, Jerusalem, Israel

$\star \star \star$ ) Department of Gynecology, Shaare Zedek

$\star \star \star)$ Department of Cardiothoracic Surgery, Shaare

Zedek Medical Center, Jerusalem, Israel 
443 physicians and 114 medical students. Most physicians would correctly examine and document the injuries, but only $59 \%$ would report their suspicions of violence to the Ministry of Health. Though $60 \%$ of physicians objected in principle to the use of torture, a majority endorsed the use of physical and psychological pressure during interrogation. Moreover, 29\% of physicians thought it is permissible for physicians to examine detainees and verify their health so that torture can begin or continue. Discussion: Our study shows that there is a need for development and implementation of treatment and reporting protocols as well as educational programs concerning the ethical and legal requirements of physicians towards detainees and prisoners in Israel. Limitations of our study are discussed.

Keywords: Violence, prisoners, torture, attitude.

\section{Introduction}

Violence is recognized as a leading worldwide public health problem. ${ }^{1}$ In many countries legislation has been passed which mandates that health professionals recognize, treat and report incidents of suspected violence to prevent its recurrence. Studies have focused on high-risk groups, like women, children, and the elderly who might be abused and neglected. ${ }^{2,3}$

Prisoners and detainees are particularly vulnerable with respect to violence. In a survey conducted in 13 American state prisons, $13-35 \%$ of all prisoners reported violence by another prisoner and $8-32 \%$ reported violence by a staff member. ${ }^{4}$ In a study conducted in 33 prisons in Germany, more than $25 \%$ of the prisoners reported being physically victimized within a fourweek period. ${ }^{4}$ With respect to detainees, a study of medical examinations performed while under police custody found that $25 \%$ of detainees reported suffering from violence, $58 \%$ of those by a police officer. ${ }^{5}$ It should also be noted that victims in custody may be reluctant to report on violence by law enforcement officials. Furthermore, in some cases the treating physician may be employed by the police or the detention center and thus have loyalties which interfere with his/ her obligation to the patient. ${ }^{6}$

Emergency medicine departments are a first contact point for victims of violence and can have a large impact on the medical and legal outcomes of such cases. Forensic knowledge and sometimes awareness is still largely lacking among physicians. ${ }^{7}$ In a survey of academic emergency physicians in the USA, it was reported that $99.8 \%$ of the respondents believed excessive force is used by law enforcement agents and that $97.8 \%$ had managed such cases. Most of these instances went unreported, most surveyed departments had no policies and the physicians surveyed had not received training for such cases. ${ }^{8}$ In Israeli detention facilities, small clinics exist, but most need to refer injuries requiring more than a physical examination to a hospital emergency room, thus all physicians working in the emergency department may come in contact with such cases.

In Israel, various articles of legislation as well as regulatory directives issued by the Ministry of Health (MOH) have aimed to improve the recognition and treatment of violence within medical settings. In 2003, the $\mathrm{MOH}$ issued a directive for the appointment of permanent committees for domestic violence, sexual exploitation and neglect of minors and incapacitated adults, ${ }^{9}$ which were charged with the implementation of proper training and treatment within the Israeli health-care system. Persons in police custody, detention or imprisonment are not explicitly included in the directive, although 
they are at risk of suffering violence, ranging from maltreatment to torture. ${ }^{10}$ That said, the $\mathrm{MOH}$ has established a special committee that is charged with examining reports by health personnel of cases of suspected violence by law enforcement agents. ${ }^{11}$ However, its current status is unclear, as are its purview and activity.

The true dimensions of violence against detainees and prisoners in Israel are, as yet, unknown. An Israeli media outlet found that $18 \%$ of Israeli citizens report they have experienced police violence. ${ }^{12}$ Journalists and human rights organizations in Israel report on the continued mistreatment and torture of prisoners by Israeli security forces. ${ }^{13,14}$

In addition to proper medical treatment of injuries, full treatment must include measures to protect the patient from further harm in the short term, and ensure reporting, with an eye towards redressing past injuries and preventing new cases.

Our survey related to possible obstacles which may hinder full and proper treatment of such cases including documentation and reporting, as well as the attitudes of physicians towards the use of violence and torture by the state. ${ }^{15,16}$ Comments of physicians regarding any past experiences in which they suspected that their patient had suffered abuse by law enforcement officials are also presented.

\section{Methods}

We distributed an anonymous questionnaire through the Israeli Medical Association (IMA) to their members, and through the Hebrew University Faculty of Medicine to current medical students. In January 2014, these two institutions sent a single invitation to take part in the survey by email, including a short cover letter and a link to the questionnaire on an accessible internet platform. Replies were collected anonymously, identified only by timestamp and demographic data including sex, age and professional status. The questionnaire related to various elements in the treatment of potential victims of violence within psychiatric and detention facilities. Of these, only the questions regarding violence against prisoners and detainees with respect to which there is a legal and professional standard of care are reported here, namely, the need for documentation and reporting with informed consent in cases of suspected violence against detainees and prisoners. In addition, we report on the respondent's past experience in caring for a patient whom he or she suspected had suffered such violence, and questions concerning the respondent's attitude to torture. The attitude questions were adapted and translated from a previously published article. ${ }^{16}$ The additional survey questions, not reported in this paper, relate to a number of important issues such as patient privacy, shackling, and protective hospitalization in the case of detainees and prisoners, on which there is less consensus. A second comparable set of questions regarding a patient with psychiatric illness who reports abuse within a mental health facility may be reported in a future paper. Respondents were requested to rate their agreement level to various statements on a scale from 1 to 5 , from 'completely agree' to 'completely disagree'. Respondents rating 1 or 2 were tallied as agreeing with the statement, and 4 and 5 as disagreeing. Percentages were calculated as a proportion of all responses given to each question.

The $\mathrm{Chi}^{2}$ was applied for testing the association between two categorical variables. All tests applied were two-tailed and a p-value of $5 \%$ or less considered statistically significant. Prior to administration of the survey, we received approval of the Internal 
Table 1: Documentation and reporting, percentage affirmed by statement

\begin{tabular}{|c|c|c|c|}
\hline & Physicians & Students & $\mathrm{CHI}^{2}$ \\
\hline 'I would document the patient's complaint of violence in his chart.' & $95.0 \%$ & $93.6 \%$ & $\mathrm{p}=0.73$ \\
\hline 'I would document the patient's injuries and photograph them.' & $80.1 \%$ & $81.5 \%$ & $\mathrm{p}=0.63$ \\
\hline 'I would report the incident to the $\mathrm{MOH} . '$ & $59.7 \%$ & $68.8 \%$ & $\mathrm{p}=0.07$ \\
\hline 'I may report the incident only if I received the patients approval.' & $19.0 \%$ & $22.0 \%$ & $\mathrm{p}=0.2$ \\
\hline
\end{tabular}

(Questions are translated from the survey). $\mathrm{CHI}^{2}$ comparison between answers of physicians and students in our study.

Ethics Review Board of Shaare Zedek Medical Center.

\section{Results}

We received answers from 443 physicians (2.2\% of IMA members as of 2012) and 114 medical students (who made up $10 \%$ of those approached). ${ }^{17}$ Low response rates are due partially to a single invitation to participate in the study. Reports of technical difficulties in opening the survey from certain institutional email accounts were also received. Among the physicians who responded, $54.9 \%$ were male compared with $59.2 \%$ of all physicians working in the field in Israel. The comparison of the age distribution of our sample to that of the national distribution of physicians (Figure 1) shows an increased rate of young physicians, under 40 year of age, among our respondents with a compensatory drop among the 50-60 year old group. As the rate of women physicians is increasing in Israel, this may account for the higher rate of women in our study. ${ }^{18}$

Respondents were asked to consider their actions in the case of a prisoner or detainee presenting in the emergency department accompanied by law enforcement officials, with bruising and signs of violence and complaining that he was beaten during interrogation (Table 1). Almost all respondents answered that they would document the patient's complaint in his chart, and most would also document his injuries in writing and photographs. Only $62 \%$ of respondents would report the incident to the $\mathrm{MOH}$ and only $20 \%$ stated that patient consent was a necessary precondition for such a report. There was no significant difference between student and physician answers to these questions.

Respondents were asked if they had treated a patient that they suspected had suffered violence during his arrest or interrogation. $13.8 \%$ of physicians $(n=48)$ affirmed that they had, and most of these $(n=36)$ added free text commentary regarding the case and their treatment in the space supplied. The most common

Figure 1: Distribution of age of physicians - respondents of our survey compares with physicians in Israel generally

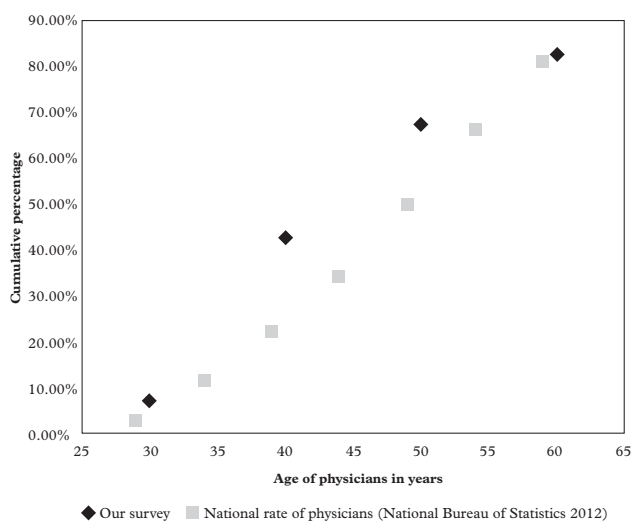


comment was that they had involved a social worker and in some cases reported to the police and in a few cases to a more senior physician. Two physicians had thought the complaint was false, one of these stating that a psychiatrist determined that it was only a ploy to get better conditions, the other stating that since the patient's bruises seemed to be older than his arrest "he was a liar". One respondent wrote that the patient had said that he had fallen during the arrest and that after reading the questionnaire he thinks that he might have been naïve to believe that.

The comments received also highlighted Israel's mandatory military service, which applies predominantly to Jewish citizens. Many continue military service in the reserve force and physicians often serve as military physicians. Five respondents related incidents from their experience as military physicians, including two who described significant difficulties: one of them wrote that he was discharged from his position in the army after he refused to examine prisoners in interrogation facilities and declare them fit for interrogation and refused to write false information concerning the mechanism of injury. During the in-take process for prisons in Israel, there is a medical examination. One respondent wrote that during the in-take process at a military detention center he was unwilling to admit a patient whom he suspected had suffered from violence by military personnel.

Regarding the respondents' attitude towards torture, $55 \%$ of all respondents answered that torture should be permitted in exceptional cases (Table 2). Furthermore, $29 \%$ affirmed that a physician can examine and treat a prisoner in order to clear him for interrogation with use of "physical or psychological pressure". To the majority of these questions, there was no significant difference between the replies of physicians and students.

A past experience of treating a detainee or prisoner whom the physician suspected had suffered violence during his arrest or interrogation, was found to have an association with an attitude of objection towards torture (a majority of answers reflecting an objection to torture in the attitude segment) ( $25 \%$ vs. $9 \%$, Chi 2 p $<0.01$ ).

\section{Discussion}

Violence is recognized as a public health issue and much research has been done on the recognition and treatment of victims of violence by health care practitioners. Today, medical students and practitioners learn not only how to recognize and treat victims of violence, but most importantly perhaps, they learn that it is their responsibility to recognize the victims and to try and protect them from further harm. ${ }^{19,20,21}$ There is a need to address additional populations that are at risk of violence and are not properly protected. In the absence of organized systems and protocols for the reporting of such cases, the true scope of violence against prisoners and detainees in Israel is unknown. At the very least, however, the results of the current study shows that physicians in Israel do encounter such cases and lack tools and knowledge of appropriate protocol. While a low response rate inhibits us from assessing the scope of the problem, the worded replies of those physicians who encountered such cases raise a number of distressing issues. None of the respondents stated that they had reported the case to the $\mathrm{MOH}$. Some physicians reported not considering the possibility of violence due to lack of knowledge or since they did not believe their patient. In addition, the responses in some cases related to physicians' experiences working within the military, raising the issue 
Table 2: Attitude towards torture, percentage affirmed by statement (significant differences in bold.)

\begin{tabular}{|c|c|c|c|c|c|}
\hline & & & $\mathrm{CHI}^{2}$ & & $\mathrm{CHI}^{2}$ \\
\hline Statement & Physicians & Students & $\begin{array}{l}\text { Physicians vs. students, } \\
\text { current study }\end{array}$ & Bean et al ${ }^{16}$ & $\begin{array}{l}\text { Current study } \\
\text { vs. Bean et al }\end{array}$ \\
\hline
\end{tabular}

1. 'Rare exceptions for the use of torture can be condoned under extreme circumstanc-
$53.2 \%$
$60.2 \%$
$\mathrm{p}=0.42$
$35 \%$
$\mathrm{p}<0.01$

agents.'

2. 'The use of torture

to elicit information

from arrested persons

is immoral and

$60.2 \% \quad 53.7 \% \quad$ p $<0.01$

$63 \%$

$\mathrm{p}=0.61$

intrinsically wrong.'

3. 'If there is the

"slightest belief" that

life-saving information

can be obtained, it is

$42.5 \%$

$37.0 \%$

$p=0.13$

$27 \%$

p $<0.01$

permissible to use

torture.'

4. 'Under extreme

conditions, it is

permissible for

interrogators to yell a

prisoners and to use

psychological

intimidation.'

5. 'It is permissible for

physicians to examine

and treat individuals to

verify their ability to

sustain a continuation

$\mathrm{p}=0.66$

$22 \%$

$\mathbf{p}=0.01$

of interrogation with

and psychological

pressure.'

Answers by Israeli physicians and medical students, compared to answers in previous study (Bean et al.). ${ }^{16}$

of conflicting loyalties in a society where a large proportion of physicians serve as military physicians. In these cases, the physicians reported constraints on their ability to treat the patient and pressure to comply with military procedure.

As no protocol for the treatment of suspected violence against detainees and prisoners exists in Israel, physicians are required to infer from their knowledge of other cases of violence. The vast majority of respondents stated they would document the complaints of the patient and in many cases, document his or her injuries in writing and photograph them. However, with regard to reporting, respondents who attempted to 
fulfill this duty often reported the case to the police, which may be the offending party, and to a social worker who may also lack appropriate routes of action. Furthermore, the rate of respondents who stated that they would in fact report the incident to the special committee in the $\mathrm{MOH}$ is likely to be overestimated due to the phrasing the question in a leading manner. It is particularly noteworthy that, despite extensive effort, no additional public information regarding this committee could be found by the authors of this study at the time of writing and it is not listed among the committees on the $\mathrm{MOH}$ website. The only information generally available regarding the committee is a $\mathrm{MOH}$ circular declaring its establishment. ${ }^{12}$

The United Nations Convention against Torture and other Cruel Inhuman and Degrading Treatment or Punishment prohibits torture under any conceivable circumstance $^{22}$ and a high rate of respondents agreed that torture is "immoral and intrinsically wrong" (Table 2, statement 2). However, this finding is potentially undercut by responses to other questions; a fairly high number also found that "torture can be condoned under extreme circumstances by legitimate state agents" (statement 1). We speculate that while torture may be considered immoral, physicians may still support its use, considering it a necessary evil (necessity defense); the legitimacy of the perpetrators justifying their actions. Similarly, the importance of obtaining life-saving information also seems to tip the balance in favor of torture for a significant number of respondents, even if not the majority (statement 3). Interestingly, the use of yelling and psychological

${ }^{i}$ Please note that this question was adapted from the original study which read "It is permissible for physicians to treat individuals to verify their health so that torture could begin or continue." intimidation is considered acceptable by $72.9 \%$ of respondents (statement 4 ). Whilst the word 'intimidation' rather than 'torture' is used in the question, the general perception is that psychological torture is less serious than the physical. (For an in-depth discussion on the topic of psychological torture see ${ }^{23}$ ). Particular attention should be given to the issue of the involvement of medical practitioners in torture. Human rights organizations have reported on such cases. ${ }^{24}$ In our survey, almost a third of respondents supported examining and treating a detainee in order to clear him for torture. Such involvement is contrary to medical ethics. ${ }^{25,26}$

This is a preliminary study and, due to a low response rate, we cannot purport to report the true rate of such opinions among Israeli physicians. However, physicians supporting torture, even to the limited extent shown here, reflects the prevailing attitudes within the general public in Israel with regard to the permissibility of violence towards prisoners. The Israeli public polled the third lowest percentage among 25 world countries of people who opposed torture under any circumstances and the highest percentage of people who said that some degree of torture should be permitted in order to combat world terrorism. ${ }^{27} \mathrm{~A}$ recent International Committee of the Red Cross report follows similar trends. ${ }^{28}$

The weakness of this study lies in its low rate of response and the possibility of an accompanying self-selection bias; physicians who encountered cases of maltreatment may have been more likely to have answered the questionnaire for example. This limitation is similar to that of previous studies in Israel which have relied on physician surveys that selected narrow or convenience samples, or lacked information on the size and characteristics of the entire participant population. ${ }^{29}$ By supplying information regarding the 
participant population of our survey we hope to have mitigated this bias.

Prisoners and detainees are an at-risk population with regard to interpersonal violence. When treating such patients, who may have been harmed, physicians must be aware of this and have the knowledge and the tools to effectively treat these patients and protect them from further harm. In Israel, there is currently no adequate functioning body to which physicians can report such cases, and no guidelines to adhere to. The permissive attitude in Israel towards the use of torture, both among the general population and among physicians, is cause for further concern and yet another obstacle towards proper treatment. The lack of differences between the replies of physicians and students on this issue mirrors the lack of continued education and practice guidelines regarding such cases. To address these concerns the development and implementation of medical protocol and efforts of medical education are paramount.

\section{Acknowledgements}

We gratefully acknowledge statistical advice by Dr. Tali Bdolah-Abram, Hebrew University, Hadassah Faculty of Medicine, Jerusalem, Israel and the professional and kind assistance of librarian Leyla Schoen, Berliner Zentrum fuer Folteropfer, Berlin, Germany

References

1. World Health Organization. Global Status Report on Violence. Geneva: World Health Organization; 2014.

2. Eisenstat SA, Bancroft L. Domestic Violence. N Engl J Med. 1999 Sep 16;341(12):886-92.

3. Wissow LS. Child Abuse and Neglect. N Engl J Med. 1995 May 25;332(21):1425-31.

4. Pont J, Stoever H, Getaz L, Casillas, A, Wolff, H. Prevention of violence in prison - The role of health care professionals. J Forensic Leg Med. 2015 Aug;34:127-32.
5. Gahide S, Lepresle A, Boraud C, Mahindhoratep TS, Chariot P. Reported assaults and observed injuries in detainees held in police custody. Forensic Sci Int. 2012 Nov 30;223(1-3):184-8.

6. Editorial. Three-faced practice: doctors and police custody. Lancet. 1993 May 15;341(8855):1245-7.

7. Henderson E, Harada N, Amar A. Caring for the forensic population: recognizing the educational needs of emergency department nurses and physicians. J Forensic Nurs. 2012 Dec;8(4):170-7

8. Hutson HR, Anglin D, Kyriacou DN, Guirguis M, Strote F. Excessive use of force by police: a survey of academic emergency physicians. Emerg Med J. 2009 Jan;26(1):20-2.

9. Ministry of Health. Directive for the Appointment of permanent committees for domestic violence, sexual exploitation and neglect of minors and incapacitated adults. [כללי - מינוי ועדות קבועות במשפחה, ניצול מיני והזנחה של קטינים וחסרי ישע חוזר המנהל לנושא אלימות Jerusalem: Ministry of Health Israel; 2003.

10. Abu Akar F, Arbel R, Benninga Z, Aboo Dia M, Steiner-Birmanns B. The Istanbul Protocol (Manual on the Effective Investigation and Documentation of Torture and Other Cruel, Inhuman or Degrading Treatment or Punishment): Implementation and Education in Israel. Isr Med Assoc J 2014;16:137-141.

11. Ministry of Health. Committee for the examination of complaints of health personnel regarding damage to the health situation of interrogated

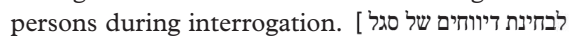
על פגיעה במצב בריאות של נחקרים במהלך החקירה מינוי וועדה רפואי] Jerusalem: Ministry of Health Israel, 2012. Hebrew. [Cited 2017 March 20] Available from: http://www.health.gov.il/NewsAndEvents/SpokemanMesseges/Pages/25012012_1.aspx

12. Gil-Har, D (producer). Thugs in Police Uniform [10 News]. [בריונים במדי משטרה, חדשות Nana10, Tel Aviv, Israel: Channel 10 news; November 7, 2010.

13. Hofstadter N. Ticking Bombs: Testimonies of Torture Victims in Israel. The Public Committee against Torture in Israel; 2007. Available from: http://stoptorture.org.il/ticking-bombs-testimoniesof-torture-victims-in-israel-may-2007/?lang=en

14. Levinson C. Torture, Israeli-style - as Described by the Interrogators Themselves. [Internet] 2017. [cited 2017 March 20] Haaretz. Available from: http://www.haaretz.com/israel-news/.premium-1.767095

15. Verma SK, Biswas G. Knowledge and attitude on torture by medical students in Delhi. Torture 2005;15(1):46-50. 
16. Bean J, Ng D, Demirtas H, Guinan P. Medical students' attitude toward torture. Torture 2008;18(2);99-103.

17. Israel Medical Association. Summary of the Association's activities 2009-2014 [2009 - סיכום פעילות הר" 2014] Israel Medical Association, 2014.

18. Israel Medical Association. The taskforce for the advancement of the position of women in medicine in Israel. מעמד הנשים ברפואה בישראל דין וחשבון 2015.

19. World Health Organisation. A global response to elder abuse and neglect: building primary health care capacity to deal with the problem worldwide: main report. World Health Organization: Geneva; 2008. Available from: http://www.who.int/ageing/ publications/ELDER_DocAugust08.pdf.

20. World Health Organisation. Responding to Intimate Partner Violence and Sexual Violence Against Women: WHO Clinical and Policy Guidelines. Geneva: World Health Organization; 2013.

21. World Health Organisation. World Report on Child Injury Prevention. Peden M, Oyegbite K, Ozanne-Smith J, et al., editors. Geneva: World Health Organization; 2008.

22. Convention against Torture and other Cruel Inhuman and Degrading Treatment or Punishment. United Nations, 1987. Available from: http://www. ohchr.org/EN/ProfessionalInterest/Pages/CAT.aspx

23. Perez-Sales P. Psychological Torture. Definition, evaluation and measurement. Routledge Taylor and Francis Group: London and New York; 2017.

24. Ballas I, Litvin A. Doctoring the evidence, abandoning the victim. [Internet] The Public Committee against Torture in Israel, Physicians for Human Rights - Israel; 2011. [Cited 2016 Oct 4] Available from: http://stoptorture.org.il/wp-content/uploads/2015/10/Doctoring-the-EvidenceAbandoning-the-Victim_November2011.pdf

25. World Medical Association. Declaration of Tokyo: Guidelines for Physicians concerning Torture, or other Cruel Inhuman and Degrading Treatment or Punishment in Relation to Detention and Imprisonment. World Medical Association; 1975 (revised 2016). Available from: http://www.wma net/en/30publications/10policies/c18/index.html

26. American Psychiatric Association. Position Statement on Psychiatric Participation in Interrogation of Detainees. [Internet] American Psychiatric Association; 2014. Available from: http://www. psychiatry.org/File\%20Library/Learn/Archives/ Position-2014-Interrogation-Detainees-Psychiatric-Participation.pdf

27. BBC World Service/Globescan/PIPA. One-third support 'some use' of torture. BBC news. [Internet] October 19, 2006. [Cited 2015 Nov 7] Available from: http://news.bbc.co.uk/2/hi/6063386.stm

28. International Committee of the Red Cross. People on War: Perspective from sixteen countries. International Committee of the Red Cross, Geneva; 2016. [Cited 2017 Jan 31] Available from: https://www.icrc.org/en/download/file/31194/ people_on_war_report.pdf

29. Heinik J, Solomesh I, Berkman P. Postgraduate Diploma Courses in Geriatric Psychiatry. IMAJ 2003; 5:356-359. Available from: https:/www. ima.org.i1/FilesUpload/IMAJ/0/53/26925.pdf 